\title{
Physicochemical properties of acorn (Quercus acutissima Carr.) tea depending on steaming and hot-air drying treatments
}

\author{
San $\mathrm{Nam}^{1}$, Yu-ri Kwon ${ }^{1,2}$, Kwang-Sup Youn ${ }^{1,2 *}$ \\ ${ }^{1}$ Department of Food Science and Technology, Catholic University of Daegu, Gyeongsan 38430, Korea \\ ${ }^{2}$ Institute of Food Science and Technology, Catholic University of Daegu, Gyeongsan 38430, Korea
}

\section{증숙 및 열풍 건조 공정에 따른 도토리차의 품질특성}

\author{
남산 $^{1} \cdot$ 권유리 ${ }^{1,2} \cdot$ 윤광섭 $^{1,2 *}$ \\ ${ }^{1}$ 대구가톨릭대학교 식품공학전공, ${ }^{2}$ 대구가톨릭대학교 식품과학연구소
}

\begin{abstract}
This study was performed to determine the effects of preconditioning process (Con, roasting; SR, steaming and roasting; HDR, hot air drying and roasting; SHDR, steaming hot air drying and roasting) and roasting on the antioxidant and physicochemical properties of acom (Quercus species) tea. Each sample was extracted in $95^{\circ} \mathrm{C}$ hot water for 5 min. The color values of lightness and yellowness were the highest in HDR, and redness were the highest in the control. The total sugar content was the highest in SHDR. Total polyphenol and total flavonoid contents of HDR tea were higher than those of teas prepared by the different processes. DPPH and ABTS radical scavenging abilities of HDR were $75.66 \%$ and $98.16 \%$, respectively, which were higher than those of other teas. In the sensory evaluation, HDR tea was ranked significantly higher than other teas in terms of flavor, taste and overall acceptability. Finally, acom tea treated with drying was superior to other treatments in antioxidant and quality properties. The result suggests that HDR can be applied to acom tea to achieve better quality and functionality.
\end{abstract}

Key words : acom (Quercus species), tea, steaming, hot-air drying, roasting

\section{서 론}

우리나라의 국민소득이 향상되면서 음식문화의 변화와 함께 건강에 대한 옥구가 증가하고 있다. 음료시장은 차별 화 및 세분화가 이루어져 특정 세대, 연령별 소비자의 다양 한 옥구를 충족시키기 위한 제품 개발이 이루어지고 있으며 일상적인 음료 섭취에서도 소비자는 자신의 기호에 맞으면 서 건강에 좋은 음료를 찾고 있다(1).

도토리는 산야에서 생산되는 견과류로 떡갈나무 갈참나 무 물참나무 상수리나무 등의 참나무과 열매의 총칭으로 우리나라 산야에는 약 28종의 도토리가 분포되어 있으며,

*Corresponding author. E-mail : ksyoun@cu.ac.kr

Phone : 82-53-850-3209, Fax : 82-53-850-3209

Received 27 October 2016; Revised 26 December 2016; Accepted 9 January 2017.

Copyright (c) The Korean Society of Food Preservation. All rights reserved.
대표적인 도토리에는 졸참나무(Quercus serrata thunberg) 의 열매와 상수리나무(Quercus autissima carruther)의 열매 를 들 수 있다(2). 우리나라에서 도토리는 춘궁기의 구황식 품으로 오래 전부터 식용 되었으나 최근에는 기능성 천연소 재로 연구되고 있다. 한방에서는 위장병, 숙취, 지사작용, 잇몸질환, 강장 등에 널리 쓰이며, 인체의 독성을 해독하는 수렴작용을 한다는 기록이 있다. 또한 저칼로리 식품으로 체중감량에도 도움을 주며 당뇨 등의 성인병 예방에도 효과 가 있다고 알려져 있다(3).

도토리의 구성성분은 전분이 $65-69 \%$, 수분이 $6.5-13.7 \%$, 조단백질이 5.8-7.8\%가 함유되어 있다(4). 도토리의 전분은 일반 전분과 달리 6-9\%의 탄닌 성분 및 단백질 친화력이 높은 다양한 형태의 가용성 폴리페놀을 함유하고 있으며 (5), 이외에도 식물성 폴리페놀 성분인 gallic acid, digallic acid, gallotannin과 $\mathrm{K}, \mathrm{P}, \mathrm{Ca}, \mathrm{Na}, \mathrm{Mg}, \mathrm{Fe}$ 과 같은 무기물질을 다량 함유하고 있어 항산화 작용, 항균 작용, 항종양에 효과 가 있다고 보고되었다(6,7). 
도토리 분말 첨가량에 따른 냉동 현미증편 반죽의 품질 에 관한 연구(8), 도토리 분말을 첨가한 쿠키의 항산화활성 및 품질특성(9) 등 도토리 분말을 첨가한 가공품 개발 연구 가 되어 있으나, 도토리 자체를 이용한 가공품 개발 및 가공 처리에 따른 도토리 가공적성에 관한 연구는 미비한 실정이 다. 따라서 도토리를 활용한 가공품 개발과 가공공정처리 를 통한 도토리의 가공적성 향상에 관한 연구가 필요하다. 증숙 공정은 증기를 이용해 열처리를 하여 세포의 구성 성분들의 변화를 유도 하여 새로운 화합물을 만들어 내거나 세포 조직을 파괴하여 유용성분 용출을 극대화하는 공정이 다(10). 열풍 건조는 타 건조방법에 비해 건조시간이 빠르며 건조과정이 간단하여 산업적으로 많이 사용되어 지고 있는 방법이며(11), 볶음 공정은 짧은 시간에 높은 온도로 처리하 여 갈변반응을 촉진시키므로 독특한 향미가 형성되어 기호 도를 높일 수 있는 방법이다(12). 증숙, 열풍 건조, 볶음 공정 같은 가공공정은 침출차 제조에 있어서 세포벽 분해, 세포내부의 공간증대, polyphenolics와 갈변 물질 간의 상호 작용을 촉진시켜 식품의 화학적 성분을 변화시키며, 생리 활성 성분 및 수용성 고형분의 추출을 용이하게 해준다(13) 따라서 본 연구에서는 도토리의 산업적 활용도 제고를 위해 증숙, 열풍 건조, 볶음 공정을 통해 도토리차를 제조 하였으며, 증숙 및 열풍 건조에 따른 도토리차의 품질 특성, 항산화 활성, 기호도 평가를 분석하여 도토리차 제품화를 위한 기초 자료를 제시하고자 하였다.

\section{재료 및 방법}

\section{실험재료}

본 실험에 사용한 도토리는 경산시 진량읍에 위치한 연 고농장에서 2015년 국내에서 수확한 도토리를 구매하여 실험에 사용하였다. 수세를 통한 이물질을 제거 후 탈피하 여 $4 \mathrm{~mm}$ 의 크기로 절단하여 사용하였으며, 실험에 사용된 모든 시약은 Sigma-Aldrich사(St. Louis, MO, USA)의 제품 을 사용하였다.

\section{증숙, 열풍 건조처리 도토리차 제조}

도토리차 제조를 위해 슬라이스한 도토리를 각각 전처리 를 통해 도토리차를 제조하였다. 증숙처리는 가정용 스팀 솥(Chefline, Bucheon, Korea)을 이용하여 10분간 증숙처리 실시하였으며, 열풍 건조는 hot-air dry oven(IRD-250, Woori Sci, Picheon, Korea)을 이용하여 $60^{\circ} \mathrm{C}$ 에서 6시간 건 조 하였다. 볶음은 도토리 $100 \mathrm{~g}$ 을 교반기가 장착된 전기 자동 볶음기(THDRE-01, Taehwan Automation Ind, Korea) 에 넣어 $250^{\circ} \mathrm{C}$ 에서 10 분 볶음 처리 하였으며, 볶음 조건은 예비실험을 통하여 관능평가를 기준으로 적합한 시간을 선정하여 설정하였다. 상기의 조건에 따라 증숙 및 열풍
건조 등의 전처리 공정 없이 도토리를 볶음한 Control, 열풍 건조 후 볶음한 HDR(hot-air drying and roasting), 증숙 후 볶음한 SR(steaming and roasting), 증숙 및 열풍 건조를 병행 처리 후 볶음한 SHDR(steaming, hot-air drying and roasting) 로 분류하여 실험에 사용하였다. 도토리차의 품질특성 및 항산화능 분석을 위해 건조 처리한 도토리 $2 \mathrm{~g}$ 에 증류수 $100 \mathrm{~mL}$ 를 가하여 $80^{\circ} \mathrm{C}$ 에서 3 분간 우려낸 다음 Whatman No. 1 여과지로 여과한 여액을 시료로 사용하였다.

\section{색도, $\mathrm{pH}$ 및 탁도}

색도는 색차계(CHDRomameter CR-200, Minolta, Tokyo, Japan)로 측정하였으며, 밝기를 나타내는 L(lightness), 적색 도를 나타내는 $\mathrm{a}$ (redness), 황색도를 나타내는 b(yellowness) 를 측정하였다. $\mathrm{pH}$ 는 침출 시료를 취하여 $\mathrm{pH}$ meter(Toledo Gmbh HG53, Greifensee, Switzerland)로 측정하였으며, 탁 도는 spectrophotometer(UV1601, Shimadzu, Kyoto, Japan) 를 사용하여 $675 \mathrm{~nm}$ 에서 흡광도를 측정하였다.

\section{총당 함량}

총당 함량은 phenol-sulfate acid법(14)에 따라 측정하였 다. 즉 침출액 $1 \mathrm{~mL}$ 에 $5 \%$ phenol $1 \mathrm{~mL}$ 와 sulfuric acid $5 \mathrm{~mL}$ 를 가하여 발색시킨 다음 20 분간 방치 후 spectrophotometer를 이용하여 $470 \mathrm{~nm}$ 에서 흡광도를 측정하였다. 총당의 정량은 glucose 표준품을 사용하여 검량선을 작성하여 실시하였다.

\section{폴리페놀 함량}

Dewanto 등(15)의 방법에 따라 추출물 $100 \mu \mathrm{L}$ 에 $2 \%$ sodium carbonate $2 \mathrm{~mL}$ 과 50\% Folin-Ciacalteu reagent 100 $\mu \mathrm{L}$ 을 가한 후 $720 \mathrm{~nm}$ 에서 흡광도를 측정하였으며 gallic $\operatorname{acid(Sigma-Aldrich~Co.)ㅇㅢ~ㄱㅓㅁㄹㅑㅇㅅㅓㄴㅇㅔ~ㅇㅢㅎㅏㅇㅕ~ㅎㅏㅁㄹㅑㅇㅇㅡㄹ~ㅅㅏㄴㅊㅜㄹㅎㅏ~}$ 였다.

\section{플라보노이드 함량}

Abdel-Hameed(16)의 방법에 따라 추출물 $100 \mathrm{~mL}$ 에 $5 \%$ sodium nitrite $0.15 \mathrm{~mL}$ 을 가한 후 $25^{\circ} \mathrm{C}$ 에서 6 분간 방치한 다음 $10 \%$ aluminium choloride $0.3 \mathrm{~mL}$ 를 가하여 $25^{\circ} \mathrm{C}$ 에서 5 분간 방치하였다. 다음 $1 \mathrm{~N} \mathrm{NaOH} 1 \mathrm{~mL}$ 를 가하고 vortex상 에서 가한 후 $510 \mathrm{~nm}$ 에서 흡광도를 측정하였으며 rutin hydrate(Sigma-Aldrich Co.)의 검량선에 의하여 함량을 산출 하였다.

\section{DPPH radical 소거활성}

Blois(17)의 방법에 따라 시액 $0.2 \mathrm{~mL}$ 에 $0.4 \mathrm{mM}$ $\mathrm{DPPH}(1,1$ diphenyl-2-picryl-hydrazyl)용액 $0.8 \mathrm{~mL}$ 를 가하여 10 분간 방치 한 다음 $525 \mathrm{~nm}$ 에서 흡광도를 측정하였으며 계산식, electron donating ability $(\%)=100-[(\mathrm{OD}$ of sample/ $\mathrm{OD}$ of control) $\times 100]$ 에 의하여 활성도를 산출하였다. 


\section{ABTS radical 소거활성}

$\operatorname{Re}$ 등(18)의 방법에 따라 $7.4 \mathrm{mM} \mathrm{ABTS}[2,2$ '-azino-bis (3-ethylbenzothiazoline-6-sulfonic acid) diammonium salt]와 $2.6 \mathrm{mM}$ potassium persulfate를 혼합하여 실온, 암소에서 24시간 동안 방치하여 radical을 형성시킨 다음 실험 직전에 $\mathrm{ABTS}$ 용액을 $732 \mathrm{~nm}$ 에서 흡광도가 $0.700 \pm 0.030$ 이 되도록 phosphate buffer saline(PBS, $\mathrm{pH}$ 7.4)로 희석하여 사용하였 다. 희석된 용액 $950 \mu \mathrm{L}$ 에 추출물 $50 \mu \mathrm{L}$ 를 가하여 암소에서 10 분간 반응시킨 후 $732 \mathrm{~nm}$ 에서 흡광도를 측정하였으며 계산식, ABTS radical scavenging ability $(\%)=100-[(\mathrm{OD}$ of sample/OD of control) $\times 100]$ 에 의하여 활성을 산출하였다.

\section{기호도 평가}

기호도 평가는 실험 목적과 관능적 품질요소를 잘 인지 하고 있는 식품공학을 전공하는 대학생 20명으로 구성된 관능요원에 의하여 5점 기호도 측도법으로 색, 향, 맛, 떫은 맛, 종합적기호도를 평가하였고, 5 점 기호도 측도법으로 실시하였다.

\section{통계처리}

모든 실험은 3회 반복으로 행하여 평균치와 표준편차로 나타내었고, 유의성 검증은 version 12의 SPSS(Statistical Package for Social Sciences, SPSS Inc., Chicago, IL, USA) software package program을 이용하여 Duncan's multiple range test를 행하였다.

\section{결과 및 고찰}

\section{도토리차의 색도}

식품의 색은 가공 시 물리적, 화학적 요인에 의해 변화하 며, 관능적 특성에 영향을 미치고, 생리활성 물질의 함량 및 항산화 활성과도 연관이 있는 것으로 알려져 있다(19).

증숙 및 열풍 건조 공정에 따른 도토리차의 색도는 Table 1 과 같았다. 밝기는 열풍 건조 후 볶음한 도토리차(HDR)에 서 높은 값을 나타내었고, 증숙 공정 후 볶음한 도토리차 $(\mathrm{SR})$ 에서 가장 낮았다. 적색도는 중숙 및 열풍 건조 공정에 처리에 따라 감소하였으며, 황색도는 증숙 및 열풍 건조 공정 처리 시 증가는 경향을 보여, HDR에서 3.47 로 가장 높은 값을 나타내었다. 이는 Lee 등(20)의 열처리에 따른 씀바귀 침출차 특성 연구에서도 같은 경향을 나타내었으 며, 도토리 당성분의 화학 반응 및 기타 성분과의 반응으로 갈색화가 일어났을 것으로 판단된다. 한편 증숙 공정을 처 리한 도토리차군은 증숙 공정을 처리하지 않은 도토리차군 보다 낮은 황색도를 나타내었으며, 이는 도토리 가공 중 증숙 공정이 도토리의 효소적 갈변을 억제하여 갈색물질이 적게 생성되었기 때문으로 판단된다. $\operatorname{Kim}$ 등(21)은 식품
갈변에 관한 연구에서 증숙과 같은 열처리 가공을 통해 갈색물질 생성이 저해된다고 보고하며 본 연구의 결과와 같았다.

Table 1. Hunter's color value of acorn (Quercus species) tea treated by steaming, drying, and roasting methods

\begin{tabular}{cccc}
\hline \multirow{2}{*}{ Sample $^{\mathrm{l})}$} & \multicolumn{3}{c}{ Hunter's clor value } \\
\cline { 2 - 4 } & $\mathrm{L}$ & $\mathrm{a}$ & $\mathrm{b}$ \\
\hline Control & $62.54 \pm 1.12^{2)(3)}$ & $0.17 \pm 0.03^{\mathrm{a}}$ & $2.97 \pm 0.13^{\mathrm{c}}$ \\
SR & $60.92 \pm 0.73^{\mathrm{d}}$ & $-0.18 \pm 0.02^{\mathrm{c}}$ & $2.76 \pm 0.11^{\mathrm{d}}$ \\
HDR & $68.98 \pm 0.05^{\mathrm{a}}$ & $-0.19 \pm 0.03^{\mathrm{c}}$ & $3.47 \pm 0.04^{\mathrm{a}}$ \\
SHDR & $65.93 \pm 0.53^{\mathrm{b}}$ & $0.02 \pm 0.02^{\mathrm{b}}$ & $3.19 \pm 0.02^{\mathrm{b}}$ \\
\hline
\end{tabular}

${ }^{1)}$ Control, roasting; SR, steaming and roasting; HDR, hot air drying and roasting; SHDR, steaming and hot air drying and roasting.

${ }^{2)}$ Values are means \pm SD of triplicate determinations.

${ }^{3)}$ Different superscripts within a column $(a-d)$ indicate significant differences $(p<0.05)$

\section{도토리차의 $\mathrm{pH}$, 탁도 및 총당함량}

증숙 및 열풍 건조 처리에 따른 도토리차의 품질특성은 Table 2과 같다. 도토리차의 $\mathrm{pH}$ 는 전처리 없이 볶음한 도토 리차(Control)에서 5.99의 값으로 가장 높은 값을 나타내었 고 이어서 증숙 및 열풍 건조 병행처리 후 볶음한 도토리차 (SHDR), 열풍 건조 후 볶음한 도토리차(HDR), 증숙 후 볶음 한 도토리차(SR) 순으로 값을 나타내었다.

탁도의 경우 전처리 없이 볶음한 도토리차(Control)에서 가장 높았고, 증숙 공정 후 볶음한 도토리차(SR)에서 가장 낮은 값을 나타내었다. 전체적으로 증숙 처리한 실험구에 서 탁도 값이 낮아지는 경향을 나타내었으며, 이는 Lee 등 (22)의 메밀순 증숙 및 건조에 따른 침출차 연구에서 또한 가용성 고형분이 감소하여 본 연구의 결과와 유의하였다.

총당 함량은 증숙 및 열풍 건조 병행처리 후 볶음한 도토 리차(SHDR)에서 $0.71 \mathrm{mg} / \mathrm{mL}$ 로 가장 높았으며, 다음으로 열풍 건조 후 볶음한 도토리차(HDR), 증숙 후 볶음한 도토 리차(SR) 순으로 나타났고, 전처리 하지 않고 볶음한 도토 리차(Control)에서 가장 낮은 값을 나타냈다. Bae 등(23)의

Table 2. $\mathrm{pH}$ turbidity and total sugar contents value of acorn (Quercus species) tea treated by steaming, drying, and roasting methods

\begin{tabular}{cccc}
\hline Sample $^{1)}$ & $\mathrm{pH}$ & $\begin{array}{c}\text { Turbidity } \\
(\mathrm{OD} 675 \mathrm{~nm})\end{array}$ & $\begin{array}{c}\text { Total sugar contents } \\
(\mathrm{mg} / \mathrm{mL})\end{array}$ \\
\hline Control & $5.99 \pm 0.02^{2) \mathrm{a})}$ & $0.08 \pm 0.00^{\mathrm{a}}$ & $0.53 \pm 0.02^{\mathrm{c}}$ \\
SR & $5.71 \pm 0.01^{\mathrm{d}}$ & $0.04 \pm 0.00^{\mathrm{d}}$ & $0.57 \pm 0.00^{\mathrm{b}}$ \\
HDR & $5.78 \pm 0.01^{\mathrm{c}}$ & $0.06 \pm 0.00^{\mathrm{b}}$ & $0.59 \pm 0.01^{\mathrm{b}}$ \\
SHDR & $5.84 \pm 0.03^{\mathrm{b}}$ & $0.05 \pm 0.00^{\mathrm{c}}$ & $0.71 \pm 0.02^{\mathrm{a}}$ \\
\hline
\end{tabular}

${ }^{1)}$ Control, roasting; SR, steaming and roasting; HDR, hot air drying and roasting; SHDR, steaming and hot air drying and roasting.

${ }^{2)}$ Values are means \pm SD of triplicate determinations.

${ }^{3)}$ Different superscripts within a column $(a-d)$ indicate significant differences $(p<0.05)$. 
연구에서 맥문동의 열처리 조건에 따른 총당을 측정한 결 과, 열처리 공정에 의해 맥문동에서 총당이 증가하는 경향 을 나타내어 본 실험과 같은 결과를 보였으며, 이는 열처리 공정에 따라 수용성 당질 함량의 변화 및 열에 의한 조직 파괴가 일어나 수용성 물질의 추출이 용이하였을 것으로 판단된다.

\section{총 폴리페놀 및 플라보노이드 함량}

페놀성 화합물은 식물계에 널리 분포되어 물질로 다양한 구조와 분자량을 가지며 페놀성 화합물의 phenol hydroxyl 기를 통해 항산화, 항암 및 항균 등의 생리기능을 가지는 것으로 알려져 있다(24).

증숙 및 열풍 건조 전처리에 따른 도토리차의 총 폴리 페놀함량은 Table 3과 같다. 총 폴리페놀함량은 열풍 건조 후 볶음한 도토리차(HDR)에서 가장 높았고 전처리 공정 없이 볶음한 도토리차(Control)에서 가장 낮았다.

플라보노이드 함량 또한 총 폴리페놀과 같이 열풍 건조 후 볶음한 도토리차(HDR)에서 높았고, 전처리 없이 볶음한 도토리차(Control)에서 낮은 함량을 나타내었다.

증숙 및 열풍 건조 전처리 공정을 거친 도토리차가 전처 리 공정을 하지 않은 도토리차보다 높은 총 폴리페놀 및 플라보노이드 함량을 나타내는 것을 확인하였으며, 이는 식품 가공 중 증숙, 열풍 건조 공정을 거치며 새로운 페놀성 화합물의 생성 및 도토리의 조직의 세포벽의 파괴가 일어난 결과 느슨해진 세포벽으로 유용 물질이 많이 용출되었을 것으로 판단된다. $\operatorname{Kim}$ 등(25)의 연구에서 또한 증숙을 통하 여 더덕의 총 페놀함량이 증가하였다고 보고하여 본 연구의 결과와 같았다.

증숙 및 열풍 건조 병행 처리 후 볶음한 도토리차(SHDR) 은 열풍 건조만을 처리한 도토리차(HDR)보다 낮은 총 폴리 페놀 및 플라보노이드 함량을 함량 나타내었다. 이는 증숙 및 열풍건조와 같은 전처리는 유용 물질의 생성 및 용출에 도움을 주지만, 과도할 경우 유용성분의 파괴를 야기하여 유용성분의 함량이 감소하였을 것으로 판단된다. Kwon 등 (26)의 증숙 및 건조 처리에 따른 우엉 차의 품질특성 연구

Table 3. Total polyphenolic, total flavonoids contents of acorn (Quercus species) tea treated by steaming, drying, and roasting methods

\begin{tabular}{ccc}
\hline Sample $^{\mathrm{l})}$ & $\begin{array}{c}\text { Polyphenols } \\
(\mathrm{mg} \%)\end{array}$ & $\begin{array}{c}\text { Flavonoids } \\
(\mathrm{mg} \%)\end{array}$ \\
\hline Control & $0.94 \pm 0.02^{2) \mathrm{d} 3)}$ & $0.33 \pm 0.01^{\mathrm{d}}$ \\
SR & $1.15 \pm 0.02^{\mathrm{b}}$ & $0.43 \pm 0.01^{\mathrm{b}}$ \\
HDR & $1.56 \pm 0.03^{\mathrm{a}}$ & $0.65 \pm 0.01^{\mathrm{a}}$ \\
SHDR & $1.03 \pm 0.02^{\mathrm{c}}$ & $0.38 \pm 0.01^{\mathrm{c}}$ \\
\hline
\end{tabular}

${ }^{1)}$ Control, roasting; SR, steaming and roasting; HDR, hot air drying and roasting; SHDR, steaming and hot air drying and roasting.

${ }^{2)}$ Values are means \pm SD of triplicate determinations.

${ }^{3)}$ Different superscripts within a column $(a-d)$ indicate significant differences $(p<0.05)$.
에서 또한 증숙 공정과 건조 공정을 병행 처리한 우엉에서 낮은 폴리페놀 함량을 보여 본 연구와 같은 경향을 나타내 었다.

\section{$\mathrm{DPPH}$ 및 $\mathrm{ABTS}$ 라디칼 소거활성}

외부 자극에 의하여 생성된 활성산소종 중 $\cdot \mathrm{OH}$ 및 $\mathrm{O}_{2} \cdot-$ 과 같은 라디칼은 세포막 지질, 단백질 및 DNA등의 산화시 켜 세포손상을 촉진한다. (+)-a-tocopherol 및 flavonoid 등과 같은 항산화제는 활성산소로 인해 생성된 지질 라디칼 등에 수소 주개로 작용하여 연쇄반응을 종결시킨다. 이 때문에 라디칼 소거는 산화에 의한 세포 손상을 막아주어 노화방 지, 항암, 항산화 같은 역할을 한다(27).

증숙 및 열풍 건조 전처리에 따른 도토리차의 라디칼 소거 활성을 확인하기 위해 DPPH 및 ABTS 라디칼을 이용 하였으며 소거활성을 측정한 결과는 Table 4 과 같다. 전처 리공정을 처리한 도토리차가 전처리 없이 볶음 처리한 도토 리차보다 높은 라디칼 소거 활성을 나타내었으며, 열풍 건 조 처리 후 볶음한 도토리차(HDR)에서 $\mathrm{DPPH}, \mathrm{ABTS}$ 라디 칼 소거능이 각각 $75.66 \%, 98.16 \%$ 로 가장 높았고, 다음으로 증숙 후 볶음한 도토리차(SR) $54.85 \%, 95.96 \%$, 증숙 및 열풍 건조 병행처리 후 볶음한 도토리차(SHDR) $43.57 \%$, 93.75\%, 전처리 없이 볶음한 도토리차(Control) $35.70 \%$, $89.58 \%$ 순으로 활성을 나타내었다.

건조 후 볶음한 도토리차(HDR)와 전처리 없이 볶음한 도토리차(Control)에서 $\mathrm{DPPH}$ 라디칼 소거능의 경우 2배 이상의 활성 차이를 나타내었으며. 이는 총 폴리페놀 및 플라보노이드 함량과 같은 경향을 나타내었고, Shin 등(28) 의 연구에서 총 페놀 함량이 증가할수록 항산화능 또한 증가 한다고 보고하여 본 실험결과와 같았다.

Table 4. DPPH and ABTS radical scavenging ability of acorn (Quercus species) tea treated by steaming, drying, and roasting methods

\begin{tabular}{ccc}
\hline Sample $^{1)}$ & $\begin{array}{c}\text { DPPH radical } \\
\text { scavenging ability }(\%)\end{array}$ & $\begin{array}{c}\text { ABTS radical } \\
\text { scavenging ability }(\%)\end{array}$ \\
\hline Control & $35.70 \pm 1.06^{2) \mathrm{d} 3)}$ & $89.58 \pm 0.06^{\mathrm{d}}$ \\
SR & $54.85 \pm 0.91^{\mathrm{b}}$ & $95.96 \pm 0.04^{\mathrm{b}}$ \\
HDR & $75.66 \pm 1.90^{\mathrm{a}}$ & $98.16 \pm 0.03^{\mathrm{a}}$ \\
SHDR & $43.57 \pm 1.00^{\mathrm{c}}$ & $93.75 \pm 0.17^{\mathrm{c}}$ \\
\hline
\end{tabular}

${ }^{1)}$ Control, Roasting; SR, Steaming and roasting; HDR, Hot air drying and roasting; SHDR, Steaming and hot air drying and roasting.

${ }^{2)}$ Values are means $\pm \mathrm{SD}$ of triplicate determinations.

${ }^{3}$ Different superscripts within a column (a-d) indicate significant differences $(\mathrm{p}<0.05)$.

\section{기호도 평가}

전처리 방법에 따른 도토리차의 색, 향, 맛, 떫은맛, 종합 적 기호도 평가 결과는 Table 5 와 같다. 색에 대한 기호도는 증숙 및 열풍건조 후 볶음한 도토리차(SHDR)에서 높았고 
증숙 후 볶음한 도토리차(SR)에서 낮은 값을 보였으나 큰 차이를 나타내지 않았다. 향의 경우 열풍 건조 후 볶음한 도토리차(HDR)에서 3.46으로 가장 높았고 전처리 공정 없 이 볶은 도토리차(Control)에서 낮은 값을 나타내었다. 증숙 및 열풍 건조한 도토리차에서 높은 점수를 받아 전처리 공정이 향의 기호도에 긍정적인 영향을 나타내었을 것으로 판단되며, 이는 Lee 등(22)의 메밀순 증숙 및 건조 실험에서 또한 증숙 및 건조에 따라 기호도가 높아진다고 보고하여 본 연구와 같은 경향을 나타내었다. 맛의 경우 또한 열풍건 조 후 볶음한 도토리차(HDR)에서 4.08로 가장 높은 값을 나타내어 향의 기호도와 같은 경향을 나타내었다. 수렴성 의 경우 증숙 후 볶음한 도토리차에서 2.62로 가장 높은 값을 보였으며, 수렴성의 경우 도토리의 수용성 탄닌에서 기인한 것으로 혀의 단백질을 응고시켜 떫은맛을 냄으로 제품의 기호도에 영향을 나타내기 때문에 맛 및 종합적 기호도 부분에서 증숙 후 볶음한 도토리차(SR)가 가장 낮은 기호도를 보인 것으로 판단되어 진다. 한편 열풍 건조 후 볶음을 실시한 도도리차(HDR)에서 색, 향, 맛에서 높은 기호도를 나타내며 종합적 기호도 3.92 로 가장 높은 기호도 평가를 받았다.

Table 5. Sensory properties of acorn (Quercus species) tea treated by steaming, drying, and roasting methods

\begin{tabular}{cccccc}
\hline Sample $^{1)}$ & Color & Flavor & Taste & Astringency & $\begin{array}{c}\text { Overall } \\
\text { acceptbility }\end{array}$ \\
\hline Control & $3.25 \pm 0.92^{2 / \mathrm{a} 3)}$ & $2.17 \pm 0.80^{\mathrm{b}}$ & $2.92 \pm 0.64^{\mathrm{b}}$ & $2.08 \pm 1.04^{\mathrm{b}}$ & $3.08 \pm 0.95^{\mathrm{b}}$ \\
SR & $3.23 \pm 0.93^{\mathrm{a}}$ & $2.42 \pm 0.64^{\mathrm{b}}$ & $1.92 \pm 0.95^{\mathrm{c}}$ & $2.92 \pm 0.86^{\mathrm{a}}$ & $1.75 \pm 0.92^{\mathrm{c}}$ \\
HDR & $3.31 \pm 0.95^{\mathrm{a}}$ & $3.46 \pm 0.88^{\mathrm{a}}$ & $4.08 \pm 0.76^{\mathrm{a}}$ & $1.85 \pm 0.99^{\mathrm{b}}$ & $3.92 \pm 0.76^{\mathrm{a}}$ \\
SHDR & $3.38 \pm 0.87^{\mathrm{a}}$ & $2.77 \pm 1.09^{\mathrm{b}}$ & $3.08 \pm 0.95^{\mathrm{b}}$ & $2.62 \pm 0.87^{\mathrm{ab}}$ & $3.00 \pm 0.91^{\mathrm{b}}$ \\
\hline
\end{tabular}

${ }^{1)}$ Control, roasting, SR, steaming and roasting; HDR, hot air drying and roasting; SHDR, steaming and hot air drying and roasting.

${ }^{2)}$ Values are means $\pm S D$ of triplicate determinations.

${ }^{3}$ Different superscripts within a column $(a-c)$ indicate significant differences $(\mathrm{p}<0.05)$.

\section{요 약}

도토리의 산업적 활용도 제고를 위해 도토리차를 제조하 였으며, 증숙, 건조 전처리에 따른 도토리차의 품질특성 및 항산화 활성을 연구하였다. 색도는 명도와 황색도의 경 우 열풍 건조 볶음한 도토리차에서 높은 값을 나타내었으 며, 적색도의 경우 전처리 없이 볶음한 도토리차에서 높았 다. $\mathrm{pH}$ 는 증숙 및 열풍 건조 공정 처리에 따라 감소하는 경향을 나타내었으며, 탁도 또한 감소하는 결과를 나타내 었다. 전처리를 실시한 도토리차에서 총당 함량이 전체적 으로 증가하였으며, 총 폴리페놀 및 플라보노이드 함량 또 한 증가하였다. 도토리차의 DPPH 및 ABTS 라디칼 소거능 평가를 실시하였으며, 열풍 건조 후 볶음한 도토리차에서
가장 높은 라디칼 소거능을 나타내어, 증숙 공정 처리군보 다 열풍 건조 공정 처리군에서 우수한 활성을 나타내는 것으로 나타났다. 도토리차의 기호도 평가에서는 열풍 건 조 후 볶음한 도토리차가 맛, 향, 종합적 기호도에서 가장 높은 값을 나타내었다. 이러한 결과를 종합하여 볼 때 전처 리 공정을 통한 도토리차 제조가 제품의 품질특성 및 항산 화활성 증진에 긍정적인 영향을 미치며, 특히 열풍 건조 후 볶는 방법을 이용하였을 때 높은 품질특성, 항산화 활성 및 기호도 평가를 나타내는 것으로 판단된다.

\section{References}

1. Han ES, Rho SN (2004) An analysis of consumption and preferences of the Korean traditional drinks by women in different age group. J East Asian Soc Diet Life, 14, 397-406

2. Lee JM, Kim SH (2008) Antioxidant properties of acorn hot-water extract using response surface methodology. Korean J Food Preserv, 15, 111-117

3. Sung IS, Kim MJ, Cho SY (1997) Effect of Quercus acutissima CARRUTHERS extracts on the lipid metabolism. J Korean Soc Food Sci Nutr, 26, 327-333

4. Kim BN (1995) A study on the literature review of acorn in Korea. Korean J Food Cook Sci, 11, 158-163

5. Shimada T, Saitoh T (2003) Negative effects of acorns on the wood mouse Apodemus speciosus. Popul Ecol, 45, 7-17

6. Yook GJ, Lee HJ, Kim MK (2002) Effect of chestnut and acorn on lipid metabolism, antioxidative capacity and antithrombotic capacity in rats. J Korean Soc Food Sci Nutr, 35, 171-182

7. Lee SH, Kim DI, Cho SY, Jung HJ, Cho SM, Park HJ, Lillehoj HS (2005) Effects of acorn (Quercus acutissima CARR.) supplementation on the level of acetylcholine and its related enzyme activities in the brain of dementia mouse model. J Korean Soc Food Sci Nutr, 34, 738-742

8. Jeong SY, Lee MK, Gwag JS, Lee SY (2016) Quality characteristics of frozen brown rice Jeung-pyun dough containing different amounts of acorn flour. Korean $\mathrm{J}$ Food Preserv, 23, 445-452

9. Joo SY, Kim OS, Jeon HK, Choi HY (2013) Antioxidant activity and quality characteristics of cookies prepared with acorn (Quercus species) powder. Korean J Food Cookery Sci, 29, 177-184

10. Song CH, Seo YC, Choi WY, Lee CG, Kim DU, Chung JY, Chung HC, Park DS, Ma CJ, Lee HY (2012) 
Enhancement of antioxidative activity of Codonopsis lanceolata by stepwise steaming process. Korean J Medicinal Crop Sci, 20, 238-244

11. Kim NM, Kim DH (2000) Quality change of cinnamon extract prepared with various drying methods. Korean J Food Nutr, 13, 152-157

12. Park MH, Sohn HJ, Jeon BS, Kim NM, Park CK, Kim AK, Kim KC (1999) Studies on flavor components and organoleptic properties in roasted red ginseng marc. J Ginseng Res, 23, 211-216

13. Redgwell RJ, Trovato V, Curti D (2003) Cocoa bean carbohydrates: roasting-induced changes and polymer interactions. Food Chem, 80, 511-516

14. Saha AK, Brewer CF (1994) Determination of the concentrations of oligosaccharides, complex type carbohydrates, and glycoproteins using the phenol-sulfuric acid method. Carbohydr Res, 254, 157-167

15. Dewanto V, Wu X, Adom KK, Liu RH (2002) Thermal processing enhances the nutritional value of tomatoes by increasing total antioxidant activity. J Agric Food Chem, 50, 3010-3014

16. Abdel-Hameed ESS (2009) Total phenolic contents and free radical scavenging activity of certain Egytian Ficus species leaf samples. Food Chem, 114, 1271-1277

17. Blois MS (1958) Antioxidant determination by the use of a stable free radical. Nature, 181, 1199-1200

18. Re R, Pellegrini N, Proteggente A, Pannala A, Yang M, Rice-Evans C (1999) Antioxidant activity applying an improved ABTS radial cation decolorization assay. Free Radic Biol Med, 26, 1231-1237

19. Pellegrini N, Chiavaro E, Gardana C, Mazzeo T, Contino D, Gallo M, Riso P, Fogliano V, Porrini M (2010) Effect of different cooking methods on color, phytochemical concentration, and antioxidant capacity of raw and frozen Brassica vegetables. J Agric Food Chem, 58, 4310-432120. Lee KS, Kim GH, Kim HH, Kim ES, Park HM, Oh MJ (2008) Quality characteristics of tea thermally processed from dried Lxeris dentata root. Korean J Food Preserv, 15, 524-531

21. Kim HS, Han MR, Chang MJ, Kim MH (2008) Study of browning and caking reduction techniques in onion powder. Food Eng Prog, 12, 269-274

22. Lee GD, Yoon SR, Kim JO, Hur SS, Seo KI (2004) Monitoring on the tea with steaming and drying process of germinated buckwheat. J Korean Soc Food Nutr, 33, 212-217

23. Bae KM, Park SH, Jung KH, Kim MJ, Hong SH, Song YO, Lee HS (2010) Effects of roasting conditions on physicochemical properties and sensory properties of Liripis tuber. J Korean Soc Food Sci Nutr, 39, 1503-1508

24. Choi YH, Kim KH, Kang MY (2001) Varietal difference in processing and sensory characteristics of Sikhye in rice. Korean J Breed, 33, 65-72

25. Kim JS, Choi WS, Chung JY, Chung HC, Lee HY (2013) Enhancement of cosmeceutical activity from Codonopsis lanceolata extracts by stepwise steaming process. Korean J Medicinal Crop Sci, 21, 204-212

26. Kwon YR, Youn KS (2014) Physicochemical of burdock (Arctium lappa $\mathrm{L}$ ) tea depending on steaming and roasting treatment. Korean J Food Preserv, 21, 646-651

27. Moreno MIN, Isla MI, Vattuone MA (2000) Comparison of the free radical-savenging activity of propolis from several regions of Argentina. J Ethnopharmacol, 71, 109-114

28. Shin EH, Park SJ, Choi SK (2011) Component analysis and antioxidant activity of Opuntia ficus-indica var. saboten. J East Asian Soc Dietary Life, 21, 691-697 